\title{
Combined Use of NMR, LC-ESI-MS and Antifungal Tests for Rapid Detection of Bioactive Lipopeptides Produced by Bacillus
}

\author{
Mara Silva ${ }^{1,2}$, António Pereira',2, Dora Teixeira1,2, António Candeias ${ }^{2}$, Ana Teresa Caldeira ${ }^{1,2 *}$ \\ ${ }^{1}$ Chemistry Department, School of Science and Technology, Évora University, Évora, Portugal \\ ${ }^{2}$ HERCULES Laboratory, Évora University, Évora, Portugal \\ Email: ^atc@uevora.pt
}

How to cite this paper: Silva, M., Pereira, A., Teixeira, D., Candeias, A. and Caldeira, A.T. (2016) Combined Use of NMR, LC-ESIMS and Antifungal Tests for Rapid Detection of Bioactive Lipopeptides Produced by Bacillus. Advances in Microbiology, 6, 788-796. http://dx.doi.org/10.4236/aim.2016.610077

Received: April 29, 2016

Accepted: September 3, 2016

Published: September 6, 2016

Copyright $\odot 2016$ by authors and Scientific Research Publishing Inc. This work is licensed under the Creative Commons Attribution International License (CC BY 4.0).

http://creativecommons.org/licenses/by/4.0/

(c) (i) Open Access

\begin{abstract}
The science and technology interact with the art in several ways. Biotechnological coupled with analytical approaches can play an important role in protecting and preserving cultural heritage for future generations. Many microorganisms influenced by environmental conditions are the main responsible for biological contamination in built heritage. Biocides based on chemical compounds have been used to mitigate this problem. Thus, it is vitally important to develop proper remediation actions based on environmentally innocuous alternative. Bacillus specie is emerging as an optimistic alternative for built heritage treatment due to their capacity to produce secondary metabolites with antagonistic activities against many fungal pathogens. Therefore, the intent of this work was to access a rapid evaluation of antifungal potential of bioactive metabolites produced by Bacillus strains and simultaneously their characterization using spectroscopic (NMR) and chromatographic techniques (LCESI-MS). The high antifungal activity obtained for Bacillus sp. active compounds produced in this study confirms the great potential to suppress biodeteriogenic fungi growth on historical artworks. Additionally, the proposed methodology allowed to access bioactive metabolites produced without need of the laborious total previous isolation and could be used as a viable alternative to be employed for screening and production of new green biocides.
\end{abstract}

\section{Keywords}

Lipopeptides, Bacillus sp., Biodegradation/Biodeterioration, Natural Biocides, Nuclear Magnetic Resonance, Liquid Chromatography Coupled to Mass Spectrometry 


\section{Introduction}

The problems caused by lack of proper preservation of historical built heritage often only come to people's attention when a tragedy occurs such as a fire or collapse. Far from the eyes of most, silence threats lurking permanently our cultural heritage. Microorganisms, including bacteria, fungi, algae and lichens, influenced by environmental conditions are the main biodeteriogens agents responsible for esthetical damage and structural damage [1]. Colonization of heritage structures by fungi of the genera Penicillium, Cladosporium, Alternaria, Curvularia, Dreschlera, Chaetomium, Fusarium, Trichoderma, Gliomastix, Aureobasidium and Mucor can induce discoloration and deterioration of its surface, leading to the appearance of stains that alter the color of painted layer [2]-[4].

The procedure of controlling biodegradation/biodeterioration of artworks with minimal environmental impact it is a major challenge for the professionals responsible for the conservation and preservation of built heritage [5]. The biocides commonly used in a restoration/conservation intervention are chemical biocides like inorganic compounds ( $\mathrm{Na}$ and $\mathrm{Ca}$ hypochlorite) and very complex organic ones such as the Quaternary Ammonium Compounds (Preventol R50, Neo-Desogen) that constitute a serious environmental and human health issue that is urgent to solve [6]. The solution may be closer than ever.

Bacillus species produce a great diversity of secondary metabolites with biological activity [3] [5], namely they are well known to possess antagonistic activities against many fungal pathogens [7]. These strains, in response to nutritional stress, activate a variety of processes including sporulation, synthesis of extracellular degradative enzymes and antibiotic production [8].

Some strains of Bacillus subtilis and Bacillus amyloliquefaciens have been referred to produce antifungal peptides [9]-[11]. The lipopeptides surfactin, fengycin and iturin are amphiphilic membrane-active biosurfactants with potent antifungal activities [12] which can be used as additive in new harmful and environmental friendly biocides.

The aim of this study was to access a rapid evaluation of antifungal potential of bioactive metabolites produced by Bacillus strains and simultaneously their characterization using NMR and LC-ESI-MS analysis without need of previous isolation.

\section{Materials and Methods}

\subsection{Microorganisms and Growth Conditions}

The strains of Bacillus sp. CCMI 1051, CCMI 1052 and CCMI 1053 were isolated from healthy Quercussuber in the south of Portugal and identified according with morphological, physiological and biochemical characteristics and by 16S rDNA sequence analysis (accession number AY785773, AY785775 and AY785774, respectively) [9]. Bacillus cells were maintained on Nutrient Agar (HIMEDIA) slants and stored at $4{ }^{\circ} \mathrm{C}$. The fungal cultures were maintained on malt extract agar (HIMEDIA) slants and used as test microorganisms. The strains Mucor sp., Alternaria sp., Penicillium sp. and Cla- 
dosporium sp., belonging to the laboratory collection (HERCULES-Biotec laboratory, Évora University), were isolated from biodegraded mural paintings, being also associated with known pathologies [4] [13].

\subsection{Bioactive Compounds Production}

For the production of bioactive compounds Bacillus sp. CCMI 1051, CCMI 1052 and CCMI 1053 cells were cultivated in $2 \mathrm{~L}$ of Nutrient Broth (HIMEDIA) medium and incubated for 48 hours at $30^{\circ} \mathrm{C}$ in an orbital shaker at $150 \mathrm{rpm}$ (IKA KS 4000 I control). After 48 hours (stationary-phase) of culture growth, the bacterial cells were removed from the culture broth by centrifugation $\left(10,000 \times \mathrm{g}\right.$ for $10 \mathrm{~min}$ at $\left.4^{\circ} \mathrm{C}\right)$. The supernatant were stored at $-80^{\circ} \mathrm{C}$ and lyophilized for further analysis.

\subsection{Column Chromatography}

Antimicrobial compounds in lyophilized cell-free supernatant cultures were solubilized in $\mathrm{CHCl}_{3} / \mathrm{CH}_{3} \mathrm{OH} / \mathrm{H}_{2} \mathrm{O}$ (65:35:5) and purified by flash column chromatography on silica gel (Merck, Kieselgel 60 with $0.040-0.063 \mathrm{~mm}$ ) using the system $\mathrm{CHCl}_{3} / \mathrm{CH}_{3} \mathrm{OH} /$ $\mathrm{H}_{2} \mathrm{O}$ (65:35:5) as eluent. The bioactive compounds purification was monitored by thin layer chromatography (Merck, Kieselgel GF 254, $0.2 \mathrm{~mm}$ ) using the same eluent.

\subsection{Antifungal Assay}

Fungal spore suspension of Mucor sp., Alternaria sp., Penicillium sp. and Cladosporium sp. were prepared by adding loopful of hyphae and spores from a Malt Extract Agar (MEA) slant incubated at $25^{\circ} \mathrm{C}$ for 7 days, in $15 \mathrm{~mL}$ of $\mathrm{NaCl} 0.85 \%$ solution. The suspension was filtered by sterilized cotton or triple gauze. A $10^{6} \mathrm{CFU} / \mathrm{mL}$ spore suspension was obtained through dilutions and fungal suspensions were incorporated in MEA at $45^{\circ} \mathrm{C}$ in Petri dishes. Filter paper discs (Macherey-Nagel 827 ATD) with 13 millimeters of diameter impregnated with $20 \mu \mathrm{L}$ of Bacillus culture broth after cells removed were placed on the agar. The Petri dishes were incubated at $25^{\circ} \mathrm{C}$ for $48-72 \mathrm{~h}$. Antifungal activity was indicated by the formation of an inhibition halos around the discs.

\subsection{LC-ESI-MS Analysis}

Before and after compounds separation, the different fractions obtained was filtered with a $0.45 \mu \mathrm{m}$ nylon filter (VWR International, West Chester, PA, USA), and a $10 \mu \mathrm{L}$ sample was analysed by liquid chromatography coupled to mass spectrometry (LC-MS).

LC-ESI-MS analyses were carried out in a LCQ Advantage Thermo Finnigan mass spectrometer equipped with an electrospray ionization (ESI) source and using an ion trap mass analyzer. The conditions of lipopetides analysis were: capillary temperature $300{ }^{\circ} \mathrm{C}$, source voltage $5.0 \mathrm{kV}$, source current $100.0 \mathrm{~A}$, and capillary voltage $22 \mathrm{~V}$, in positive mode. The mass spectrometer equipment was coupled to an HPLC system with 
autosampler (Surveyor ThermoFinnigan). The analytical column was a reversed phase Zorbax Eclipse (C18, particle size $5.0 \mu \mathrm{m}, 150 \mathrm{~mm} \times 2.4 \mathrm{~mm}$ ). The chromatographic separation was performed with a gradient program using acetonitrile as eluent $\mathrm{A}$ and water acidified with $0.1 \%(\mathrm{v} / \mathrm{v})$ formic acid as eluent $\mathrm{B}$, at a flow rate of $0.3 \mathrm{~mL} \cdot \mathrm{min}^{-1}$. The elution program was as following: linear gradient from $20 \%$ to $50 \%$ of A (0 - 10 $\mathrm{min}$ ) and from $50 \%$ to $100 \%$ of $\mathrm{A}(10-40 \mathrm{~min})$.

\subsection{Nuclear Magnetic Resonance (NMR)}

${ }^{1} \mathrm{H}$ NMR spectra were recorded on a Bruker Avance III HD 400 spectrometer at 400 $\mathrm{MHz}$ in DMSO-d6 (Euriso-top). ${ }^{1} \mathrm{H}$ shifts are reported relative to the ${ }^{1} \mathrm{H}$ signal of DMSO-d6 $(\delta=2.50 \mathrm{ppm})$ [14] [15].

\section{Results and Discussion}

\subsection{Antifungal Activity Assessment}

Several studies have described that bacteria of genera Bacillus are worthy to be used as antifungal substances producer including extracellular lipopeptides for versatile applications [16]-[19]. To detect these biosurfactants several qualitative tests are available [20].

In this work a new methodological scheme using analytical and biological approaches was established in order to access bioactive metabolites produced by Bacillus strains and simultaneously their characterization without need of the laborious total previous isolation.

The final propose is the production of a new alternative for commercial toxic biocides used in heritage context thought the development of green biocides produced by harmful Bacillus species.

After $48 \mathrm{~h}$ of Bacillus sp. CCMI 1053 culture, the supernatants of liquid cultures were tested against the selected biodeteriogenic fungal strains isolated from biodegraded mural paintings: Mucor sp., Alternaria sp., Penicillium sp. and Cladosporium sp. (Table 1). These fungal strains represent different fungi genera commonly found in biodegraded heritage materials and their inhibition is an important issue in this context.

Antifungal assays show a high inhibition zone for all free cells culture broths produced against biodeteriogenic fungi. Nevertheless the Bacillus sp. CCMI1053 display a major antifungal potential against Penicillium sp., confirmed by the formation of an inhibition halo of $37.44 \mathrm{~mm}$ (Figure 1 and Table 1). Results obtained in this work

Table 1. Inhibition halos of Bacillus sp. against the biodeteriogenic fungi.

\begin{tabular}{ccccc}
\hline \multirow{2}{*}{ Bacillus sp. } & \multicolumn{4}{c}{ Inhibition halos $(\mathrm{mm})$} \\
\cline { 2 - 5 } & Mucorsp. & Alternaria sp. & Penicilliumsp. & Cladosporium sp. \\
\hline CCMI 1051 & $25.67 \pm 1.00$ & $23.11 \pm 0.93$ & $23.67 \pm 0.50$ & $22.11 \pm 0.19$ \\
CCMI 1052 & $18.22 \pm 0.97$ & $17.89 \pm 0.33$ & $18.89 \pm 1.05$ & $17.33 \pm 0.03$ \\
CCMI 1053 & $27.33 \pm 0.87$ & $22.33 \pm 0.71$ & $37.44 \pm 1.83$ & $26.67 \pm 1.41$ \\
\hline
\end{tabular}




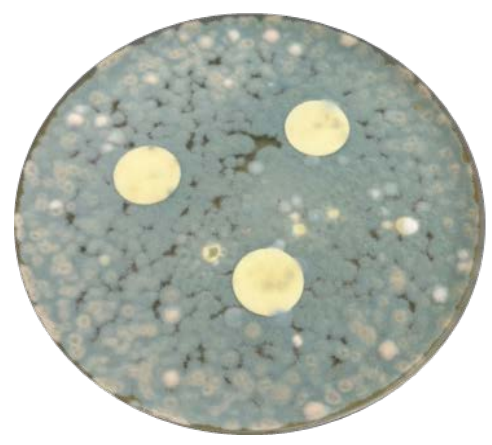

(a)

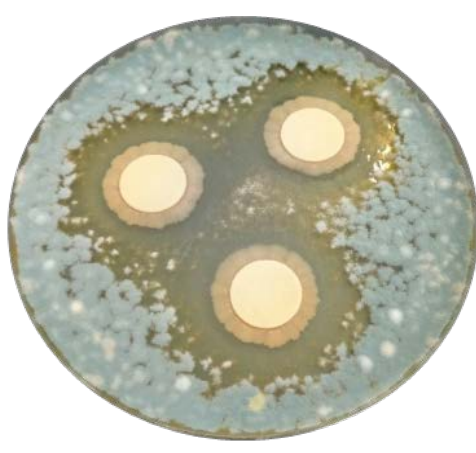

(b)

Figure 1. Antifungal activity of biocides against Penicillium sp. using paper disk diffusion assay. (a) Control; (b) In the presence of Bacillus sp. CCMI 1053 cell free culture Broth.

accomplish a ground-breaking research for the utilization of the compounds produced for application in heritage materials contaminated by fungal communities and confirm previous studies reporting that Bacillus strains have a height antifungal activity [10] [17] [21] [22] related to the presence of lipopeptides.

\subsection{Characterization of the Antifungal Compounds}

The ${ }^{1} \mathrm{H}-\mathrm{NMR}$ spectrum of the bioactive compounds showed signals for $\mathrm{N}$-binding protons at $\delta 6.8-8.6 \mathrm{ppm}, \alpha$-protons at $\delta 4.0-4.5 \mathrm{ppm}$ and $\beta / \gamma$-protons at $\delta 1.4-4.0 \mathrm{ppm}$ of peptide bonds (Figure 2). Additionally we can observe multiple sets of $\mathrm{A}_{2} \mathrm{~B}_{2}$ coupling pattern protons of benzene rings at $\delta 6.6-7.1 \mathrm{ppm}$ (each $\mathrm{d}, \mathrm{J} \sim 8.0 \mathrm{~Hz}$ ), methylene protons of long aliphatic chains at $\delta 1.0-1.3 \mathrm{ppm}$ and terminal methyl protons at $\delta 0.7$ - $1.0 \mathrm{ppm}$. These patterns of signals are consistent with the presence, almost exclusive, of lipopeptides, compounds made of amino acids and a fatty acid chain [14] [23]-[25].

A LC-ESI-MS spectral analysis of the cell free supernatant showed a cluster containing molecules that were observed at m/z 1031, 10451463 and 1477 (Figure 3). These peaks differ by $14 \mathrm{Da}$ suggesting a series of homologous molecules with different lengths of fatty acid chain. In the literature bacterial lipopeptides such as iturin A, surfactin and fengycin exhibited the same peak profile that the obtained with Bacillus sp. CCMI1053. Kim et al. (2010) described that the strains of Bacillus subtillis CMB32 produced lipopeptides with molecular masses estimated by 1080, 1486 and $1044 \mathrm{Da}$, corresponding to the antifungal lipopeptides iturin A, fengycin and surfactin A, respectively [26]. Caldeira et al. (2011) reported that Bacillus amyloliquefaciens CCMI1051 exhibit high levels of antagonistic properties against filamentous fungi duo to the production of compounds of masses between 1000 and $1100 \mathrm{Da}$, comparable to that of iturin and surfactin compounds between 1436 and $1478 \mathrm{Da}$, compatibles with fengycin [17].

Thus, the peaks with $\mathrm{m} / \mathrm{z}$ 1031, 1045, 1463 and 1477 could be assigned to lipopeptides. The mass spectra obtained in ESI mode shows a cluster containing molecules with a difference of $14 \mathrm{Da}$, corresponding to the loss of $\mathrm{CH}_{2}$ in the lipidic chain [9] (m/z 1031, 1045 and 1463, 1477) (Figures 3(a)-(d)). Several isoforms exist for each li- 


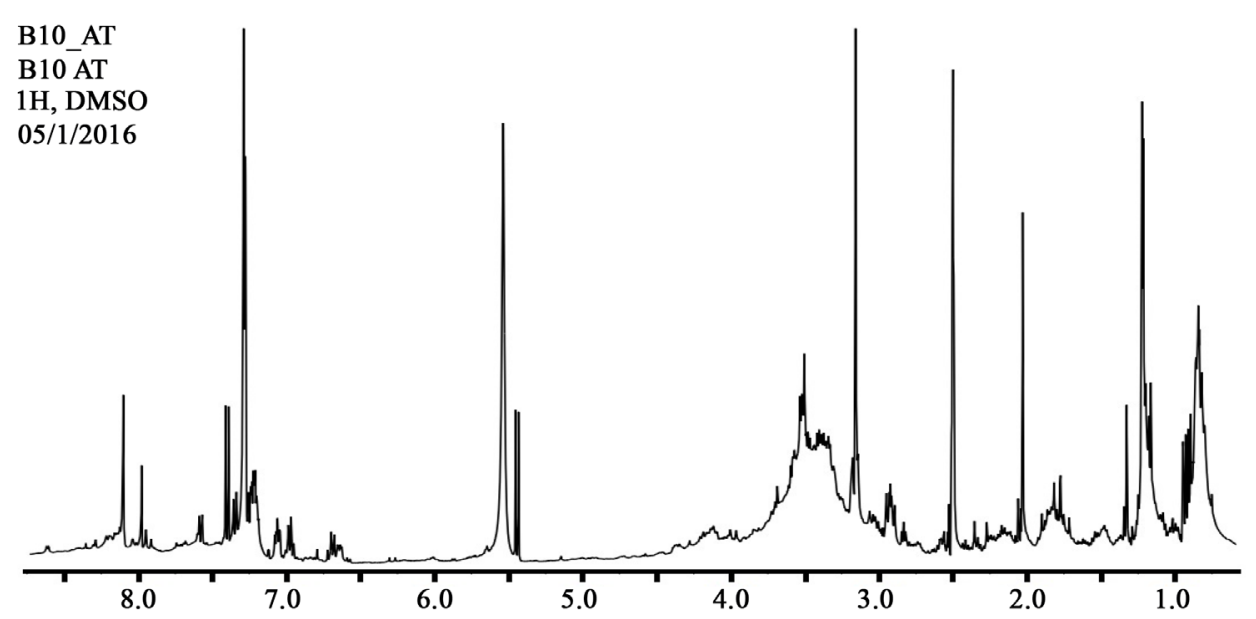

Figure 2. ${ }^{1} \mathrm{H}$-NMR spectra of the bioactive compounds produce by Bacillus sp. CCMI1053.
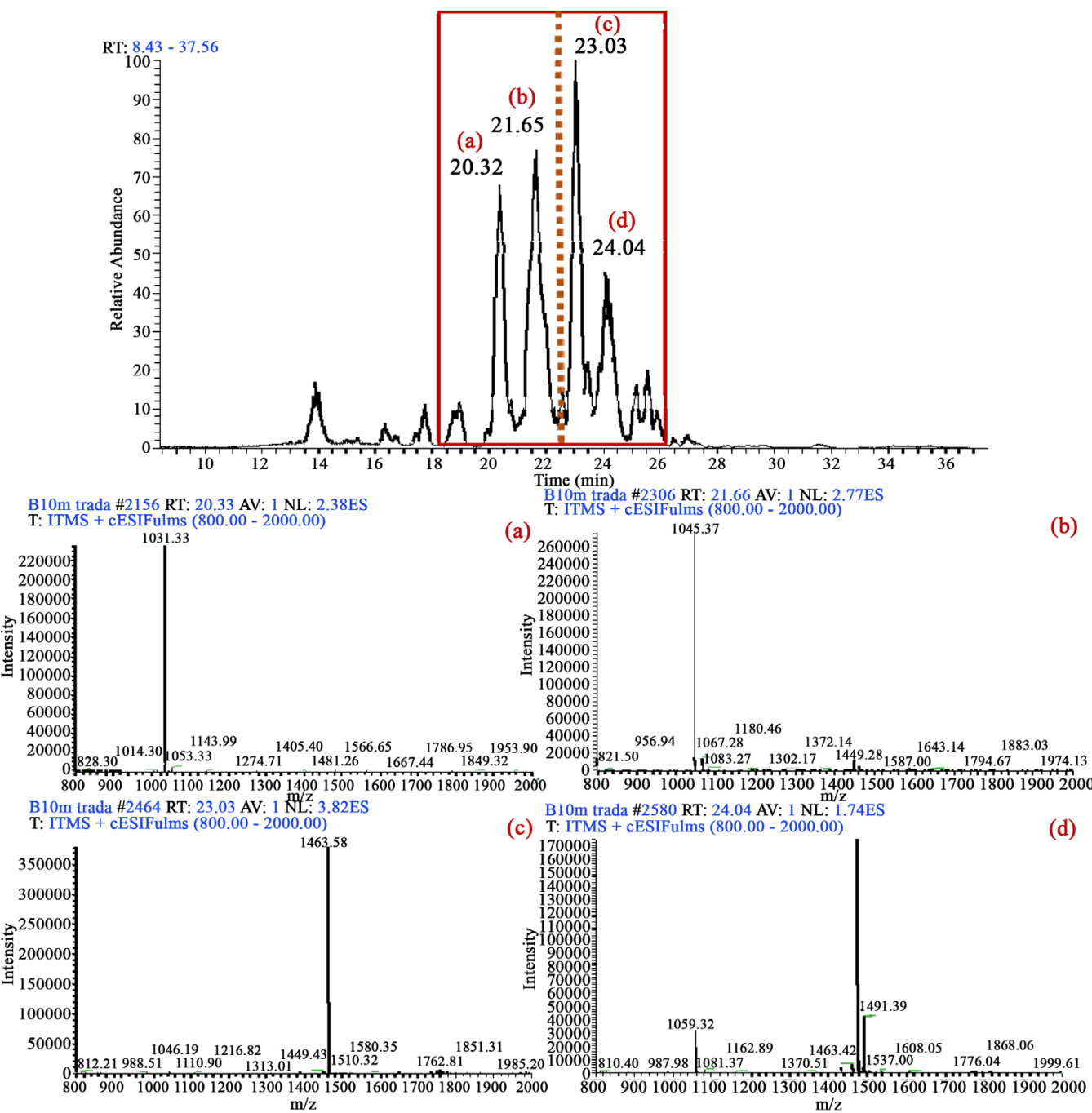

Figure 3. Total ion chromatogram of the cell free supernatant concentred by column chromatography of Bacillus sp. CCMI1053 and mass spectra corresponding to the peaks (a) m/z 1031.37; (b) m/z 1045.37; (c) $\mathrm{m} / \mathrm{z} 1463.53$ and $(\mathrm{d}) \mathrm{m} / \mathrm{z} 1477.55$. 
popeptide due to diverse producer strains and different nutritional conditions. These environments affect the substitution of amino acids in the peptidic ring and the length of lipidic chain [27].

\section{Conclusion}

In this work, a combined use of NMR and LC-ESI-MS allows a rapid identification of lipopeptides produced by Bacillus sp. CCMI1053. The proposed methodology allowed to access bioactive metabolites produced without need of the laborious total previous isolation and could be used as a viable alternative to be employed for screening and production of new green biocides.

\section{Acknowledgements}

The authors gratefully acknowledge the following funding sources "HIT3CH HERCULES Interface for Technology Transfer and Teaming in Cultural Heritage", Ref: ALT20-03-0246-FEDER-000004, and "MEDUSA-Microrganisms Monitoring and Mitigation-Developing and Unlocking novel Sustainable Approaches” Ref. ALT20-030145-FEDER-000015, co-financed by the European Union through the European Regional Development Fund ALENTEJO 2020 (Regional Operational Programme of the Alentejo).

\section{References}

[1] Pangallo, D., Chovanová, K., Šimonovicová, A. and Ferianc, P. (2009) Investigation of Microbial Community Isolated from Indoor Artworks and Air Environment: Identification, Biodegradative Abilities, and DNA Typing. Canadian Journal of Microbiology, 55, 277-287. http://dx.doi.org/10.1139/w08-136

[2] Milanesi, C., Baldi, F., Borin, S., Vignani, R., Ciampolini, F., Faleri, C. and Cresti, M. (2006) Biodeterioration of a Fresco by Biofilm Forming Bacteria. International Biodeterioration \& Biodegradation, 57, 168-173. http://dx.doi.org/10.1016/j.ibiod.2006.02.005

[3] Sterflinger, K. (2010) Fungi: Their Role in Deterioration of Cultural Heritage. Fungal Biology Reviews, 24, 47-55. http://dx.doi.org/10.1016/j.fbr.2010.03.003

[4] Rosado, T., Gil, M., Caldeira, A.T., Martins, M.D.R., Dias, C.B., Carvalho, L., Mirão, J. and Candeias, A.E. (2013) Material Characterization and Biodegradation Assessment of Mural Paintings: Renaissance Frescoes from Santo Aleixo Church, Southern Portugal. International Journal of Architectural Heritage, 8, 835-852. http://dx.doi.org/10.1007/s00216-013-7516-7

[5] Fonseca, A.J., Pina, F., Macedo, M.F., Leal, N., Romanowska-Deskins, A., Laiz, L., GómezBolea, A. and Saiz-Jimenez, C. (2010) Anatase as an Alternative Application for Preventing Biodeterioration of Mortars: Evaluation and Comparison with Other Biocides. International Biodeterioration \& Biodegradation, 64, 388-396. http://dx.doi.org/10.1016/j.ibiod.2010.04.006

[6] Camara, B., De Los Rios, A., Urizal, M., de Buergo, M.A., Varas, M.J., Fort, R. and Ascaso, C. (2011) Characterizing the Microbial Colonization of a Dolostone Quarry: Implications for Stone Biodeterioration and Response to Biocide Treatments. Microbial Ecology, 62, 299-313. http://dx.doi.org/10.1007/s00248-011-9815-x 
[7] Caldeira, A., Feio, S., Santos Arteiro, J.M. and Roseiro, J.C. (2007) Bacillus amyloliquefaciens CCMI 1051 in Vitro Activity against Wood Contaminant Fungi. Annals of Microbiology, 57, 29-33. http://dx.doi.org/10.1007/BF03175046

[8] Varadavenkatesan, T. and Murty, V.R. (2013) Production and Properties of a Lipopeptide Biosurfactant by B. subtilis subsp. Inaquosorum. Journal of Microbiology \& Biotechnology Research, 3, 63-73.

[9] Caldeira, A.T., Feio, S.S., Arteiro, J.M., Coelho, A.V. and Roseiro, J.C. (2008) Environmental Dynamics of Bacillus amyloliquefaciens CCMI 1051 Antifungal Activity under Different Nitrogen Patterns. Journal of Applied Microbiology, 104, 808-816. http://dx.doi.org/10.1111/j.1365-2672.2007.03601.x

[10] Das, P., Mukherjee, S. and Sen, R. (2008) Antimicrobial Potential of a Lipopeptide Biosurfactant Derived from a Marine Bacillus circulans. Journal of Applied Microbiology, 104, 1675-1684. http://dx.doi.org/10.1111/j.1365-2672.2007.03701.x

[11] Leifert, C., Li, H., Chidburee, S., Hampson, S., Workman, S., Sigee, D., Epton, H.A. and Harbour, A. (1995) Antibiotic Production and Biocontrol Activity by Bacillus subtilis CL27 and Bacillus pumilus CL45. Journal of Applied Bacteriology, 78, 97-108. http://dx.doi.org/10.1111/j.1365-2672.1995.tb02829.x

[12] Moyne, A.L., Cleveland, T.E. and Tuzun, S. (2004) Molecular Characterization and Analysis of the Operon Encoding the Antifungal Lipopeptide Bacillomycin D. FEMS Microbiology Letters, 234, 43-49. http://dx.doi.org/10.1111/j.1574-6968.2004.tb09511.x

[13] Rosado, T., Gil, M., Mirão, J., Candeias, A. and Caldeira, A.T. (2013) Oxalate Biofilm Formation in Mural Paintings due to Microorganisms-A Comprehensive Study. International Biodeterioration \& Biodegradation, 85, 1-7. http://dx.doi.org/10.1016/j.ibiod.2013.06.013

[14] Volpon, L., Besson, F. and Lancelin, J.-M. (2000) NMR Structure of Antibiotics Plipastatins A and B from Bacillus subtilis Inhibitors of Phospholipase A 2. FEBS Letters, 485, 76-80. http://dx.doi.org/10.1016/S0014-5793(00)02182-7

[15] Garbay-Jaureguiberry, C., Roques, B., Delcambe, L., Peypoux, F. and Michel, G. (1978) NMR Conformational Study of Iturin A, an Antibiotic from Bacillus subtilis. FEBS Letters, 93, 151-156. http://dx.doi.org/10.1016/0014-5793(78)80825-4

[16] Mandal, S.M., Barbosa, A.E. and Franco, O.L. (2013) Lipopeptides in Microbial Infection Control: Scope and Reality for Industry. Biotechnology Advances, 31, 338-345. http://dx.doi.org/10.1016/j.biotechadv.2013.01.004

[17] Caldeira, A.T., Santos Arteiro, J.M., Coelho, A.V. and Roseiro, J.C. (2011) Combined Use of LC-ESI-MS and Antifungal Tests for Rapid Identification of Bioactive Lipopeptides Produced by Bacillus amyloliquefaciens CCMI 1051. Process Biochemistry, 46, 1738-1746. http://dx.doi.org/10.1016/j.procbio.2011.05.016

[18] Cao, X.-H., Liao, Z.-Y., Wang, C.-L., Yang, W.-Y. and Lu, M.-F. (2009) Evaluation of a Lipopeptide Biosurfactant from Bacillus natto TK-1 as a Potential Source of Anti-Adhesive, Antimicrobial and Antitumor Activities. Brazilian Journal of Microbiology, 40, 373-379. http://dx.doi.org/10.1590/S1517-83822009000200030

[19] Cao, Y., Xu, Z., Ling, N., Yuan, Y., Yang, X., Chen, L., Shen, B. and Shen, Q. (2012) Isolation and Identification of Lipopeptides Produced by B. subtilis SQR 9 for Suppressing Fusarium Wilt of Cucumber. Scientia Horticulturae, 135, 32-39.

http://dx.doi.org/10.1016/j.scienta.2011.12.002

[20] Raaijmakers, J.M., De Bruijn, I., Nybroe, O. and Ongena, M. (2010) Natural Functions of Lipopeptides from Bacillus and Pseudomonas: More than Surfactants and Antibiotics. FEMS Microbiology Reviews, 34, 1037-1062. http://dx.doi.org/10.1111/j.1574-6976.2010.00221.x 
[21] Ben Slimene, I., Tabbene, O., Djebali, N., Cosette, P., Schmitter, J.M., Jouenne, T., Urdaci, M.-C. and Limam, F. (2012) Putative Use of a Bacillus subtilis L194 Strain for Biocontrol of Phoma medicaginis in Medicago truncatula Seedlings. Research in Microbiology, 163, 388397. http://dx.doi.org/10.1016/j.resmic.2012.03.004

[22] Silva, M., Rosado, T., Teixeira, D., Candeias, A. and Caldeira, A.T. (2015) Production of Green Biocides for Cultural Heritage. Novel Biotechnological Solutions. International Journal of Conservation Science, 6, 519-530.

[23] Ma, Z., Wang, N., Hu, J. and Wang, S. (2012) Isolation and Characterization of a New Iturinic Lipopeptide, Mojavensin A Produced by a Marine-Derived Bacterium Bacillus mojavensis B0621A. The Journal of Antibiotics ( Tokyo), 65, 317-322. http://dx.doi.org/10.1038/ja.2012.19

[24] Tang, J.S., Gao, H., Hong, K., Yu, Y., Jiang, M.M., Lin, H.P., Ye, W.C. and Yao, X.S. (2007) Complete Assignments of ${ }^{1} \mathrm{H}$ and ${ }^{13} \mathrm{C}$ NMR Spectral Data of Nine Surfactin Isomers. Magnetic Resonance in Chemistry, 45, 792-796. http://dx.doi.org/10.1002/mrc.2048

[25] Ruangwong, O.-U., Chang, C.-I., Lamine, S.A. and Liang, W.-J. (2012) Identification of Antifungal Compound Produced by Bacillus subtilis LB5 with Ability to Control Anthracnose Disease Caused by Colletotrichum gloeosporioides. African Journal of Microbiology Research, 6, 3732-3738.

[26] Kim, P.I., Ryu, J., Kim, Y.H. and Chi, Y.T. (2010) Production of Biosurfactant Lipopeptides Iturin A, Fengycin and Surfactin A from Bacillus subtilis CMB32 for Control of Colletotrichum gloeosporioides. Journal of Microbiology and Biotechnology, 20, 138-145.

[27] Leenders, F., Stein, T.H., Kablitz, B., Franke, P. and Vater, J. (1999) Rapid Typing of Bacillus subtilis Strains by Their Secondary Metabolites Using Matrix-Assisted Laser Desorption/Ionization Mass Spectrometry of Intact Cells. Rapid Communications in Mass Spectrometry, 13, 943-949.

http://dx.doi.org/10.1002/(SICI)1097-0231(19990530)13:10<943::AID-RCM591>3.0.CO;2-0

\section{Submit or recommend next manuscript to SCIRP and we will provide best service for you:}

Accepting pre-submission inquiries through Email, Facebook, LinkedIn, Twitter, etc. A wide selection of journals (inclusive of 9 subjects, more than 200 journals)

Providing 24-hour high-quality service

User-friendly online submission system

Fair and swift peer-review system

Efficient typesetting and proofreading procedure

Display of the result of downloads and visits, as well as the number of cited articles Maximum dissemination of your research work

Submit your manuscript at: http://papersubmission.scirp.org/ 